KASSIM AL-KHATIB, UC Cooperative Extension Weed Specialist and Director of Statewide IPM Program, Department of Plant Sciences, University of California, Davis; BRAD HANSON, UC Cooperative Extension Weed Specialist, Department of Plant Sciences, University of California, Davis; TIM MILLER, Mount Vernon Research and Extension Center, Mount Vernon, Washington; ED PEACHEY, Department of Horticulture, Oregon State University, Corvallis; RICK BOYDSTON, USDA Agricultural Research Service, Prosser, Washington

\section{Managing Glyphosate-Resistant Weeds in} \section{Glyphosate-Resistant Crops}

Iyphosate-resistant crops have been genetically 4 modified to enable plants to survive treatment following application of the herbicide glyphosate. Crops carrying the resistant genes can be treated with glyphosate during the growing season, allowing farmers greater flexibility in timing herbicide applications. Use of this herbicide in glyphosate-resistant crops has given farmers cost-effective, broad-spectrum weed control options. It has also increased the adoption of reduced or no-tillage cultural practices, resulting in a more sustainable production system. In addition, because glyphosate is strongly adsorbed to the soil, the threat of residual effects on succeeding rotational crops is negligible.

The adoption of glyphosate-resistant crops has increased dramatically in the last decade. Most of the increase in crop acreage is attributable to glyphosate-resistant soybean, corn, canola, and cotton.

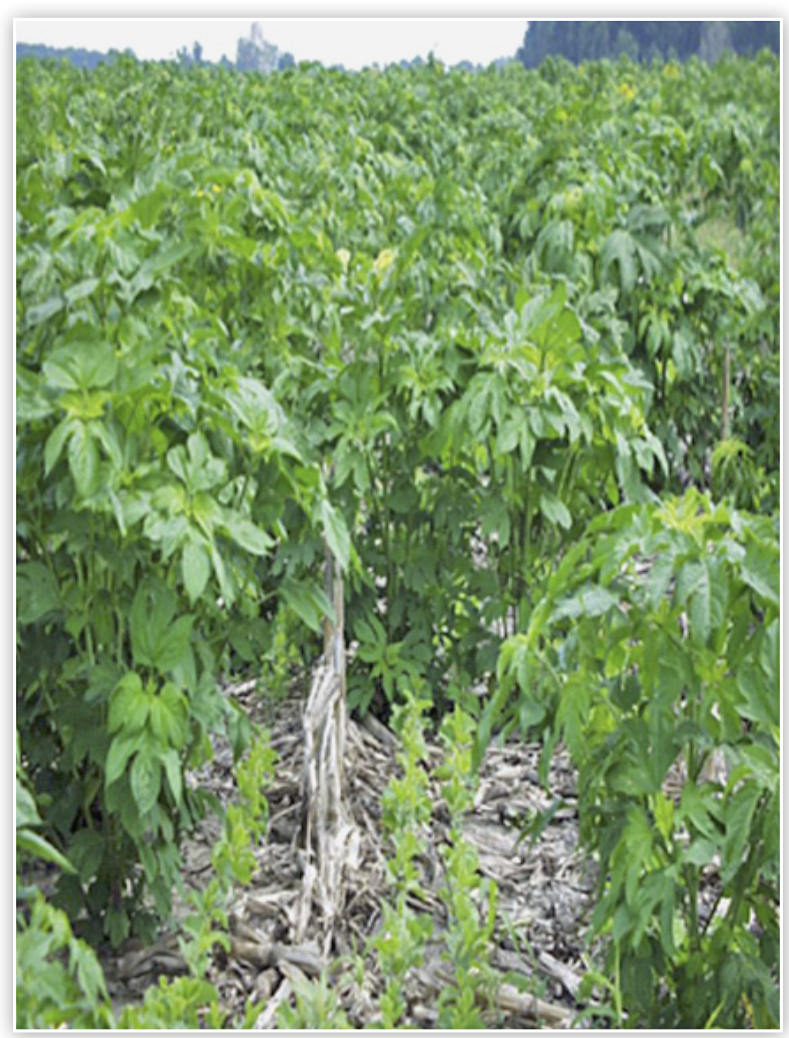


Glyphosate-resistant sweet corn, alfalfa, and sugarbeet are approved and expected to be planted in many parts of the western United States in the coming years. The outcomes of this unprecedented adoption of glyphosate-resistant crops have been many, but perhaps most dramatic is the simplification of weed control tactics; growers can now apply glyphosate at high rates and at multiple times during the growing season without concern for crop injury.

When using herbicides with short or no residual activity, such as glyphosate, optimal weed control often requires sequential herbicide applications, and the timing relative to weed emergence is important. When glyphosate is applied two or three times annually at high rates, it imposes a high selection pressure on weeds. Repeated use over several years may cause a shift in weed composition toward species that naturally tolerate glyphosate. Several weedy species that are common in the western United States-such as yellow nutsedge, common lambsquarters, black nightshade, panicle willowweed,

creeping buttercup, cheeseweed, burning nettle, filaree, purslane, and morningglory-are relatively tolerant of glyphosate. To avoid weed species shifts, it is obvious that weed management practices besides the use of glyphosate need to be integrated into glyphosate-resistant cropping systems.

With the rapid adoption of glyphosate-resistant crops and the corresponding increase in glyphosate use, the evolution of glyphosate-resistant weed populations has rapidly escalated.

Currently, there are 13 confirmed glyphosate-resistant weed species in the United States (table 1), including five species in California and Oregon (table 2, figs. 1 to 5). Glyphosate resistance is the inherited ability of a plant to survive and reproduce following exposure to a dose of glyphosate normally lethal to the wild type. Weeds contain a tremendous amount of genetic variation, and the repeated use of a single herbicide can select individuals with genetic mutations that confer resistance. Although repeated use of glyphosate can select resistant populations, no evidence has been presented to demonstrate that glyphosate induces mutations directly. Resistant individuals can exist in a field at low frequency prior to glyphosate application.
These individuals survive applications of glyphosate and reproduce to increase their numbers in a population.

Several important mechanisms can confer glyphosate resistance, including an altered glyphosate target site, changes in translocation, and gene overexpression. In contrast to many other cases of herbicide resistance, glyphosate-resistant weeds usually have relatively low levels of resistance (three- to elevenfold) compared with susceptible plants. In addition, young glyphosate-resistant weeds that are 1 to 2 inches tall are often less resistant to glyphosate than are more developed plants measuring 6 to 9 inches tall. (For converting U.S. customary units to metric units, see the table at the end of this publication.) Typically, weeds resistant to herbicides with other modes of action have similar levels of resistance at all growth stages.

In the western United States, glyphosate-resistant weeds are not widespread (see tables 1 and 2). However, because of the rapid adoption of glyphosate-resistant crops, such as corn, canola, alfalfa, cotton, and sugarbeet, as well as the declining glyphosate prices in

Table 1. Glyphosate-resistant weeds in the United States

\begin{tabular}{|l|l|c|}
\hline Common name & Scientific name & Year first confirmed \\
\hline rigid ryegrass & Lolium rigidum & 1998 \\
\hline marestail & Conyza canadensis & 2000 \\
\hline Italian ryegrass & Lolium multiflorum & 2004 \\
\hline giant ragweed & Ambrosia trifida & 2004 \\
\hline common ragweed & Ambrosia artemisiifolia & 2004 \\
\hline common waterhemp & $\begin{array}{l}\text { Amaranthus tuberculatus } \\
\text { (syn. rudis) }\end{array}$ & 2005 \\
\hline Palmer amaranth & Amaranthus palmeri & 2005 \\
\hline Johnsongrass & Sorghum halepense & 2007 \\
\hline kochia & Kochia scoparia & 2007 \\
\hline hairy fleabane & Conyza bonariensis & 2007 \\
\hline junglerice & Echinochloa colona & 2008 \\
\hline annual bluegrass & Poa annua & 2010 \\
\hline goosegrass & Eleusine indica & 2010 \\
\hline
\end{tabular}


Table 2. Glyphosate-resistant weed distribution in California and Oregon

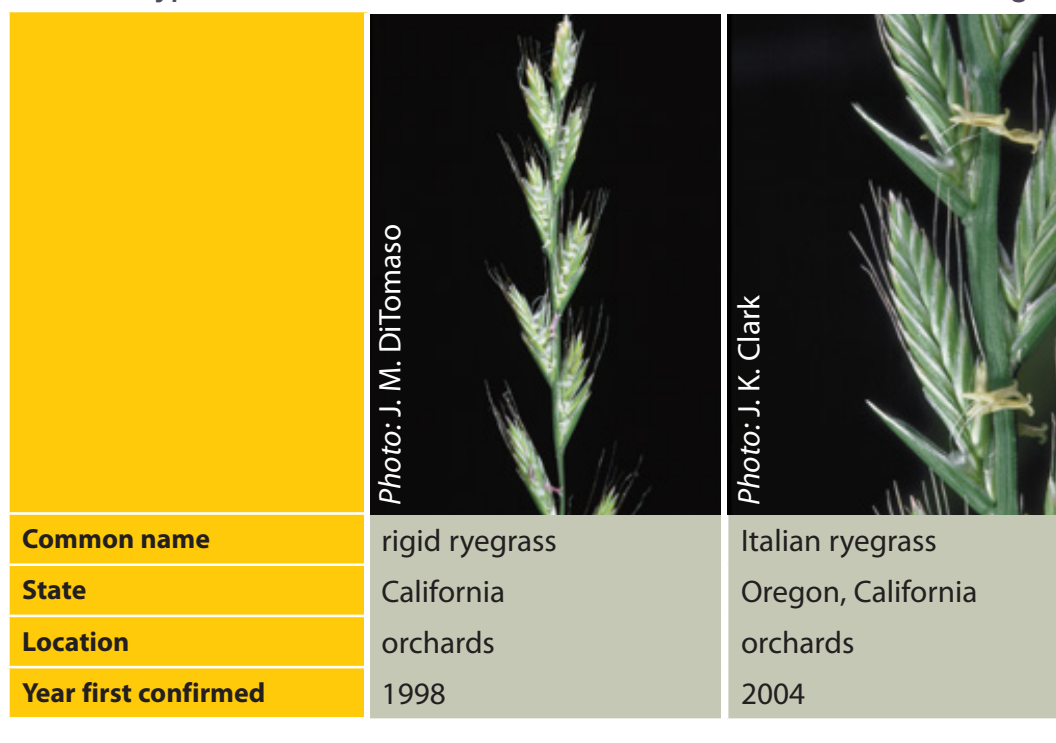

recent years, growers are more frequently using glyphosate to replace in-crop cultivation and other herbicides. The reliance on herbicides with the same mode of action for extended periods can certainly contribute to weed shifts and the selection of biotypes with resistance to glyphosate.

\section{IPM and Glyphosate-Resistant Crops}

Glyphosate-resistant crops are a powerful tool for managing weeds, but they must be used as part of an integrated pest management (IPM) program. IPM is a decision-making process to reduce risk and improve the effectiveness of weed management strategies. IPM coordinates an understanding of weed biology, environmental information, and available technology-including biological, cultural, chemical, and genetic practices-aimed at preventing economically significant pest damage. IPM principles and practices include field scouting or other detection methods, pest identification, population monitoring, and treatments. IPM programs for weeds in glyphosate-resistant crops need to consider all available weed management options appropriate to the system, including
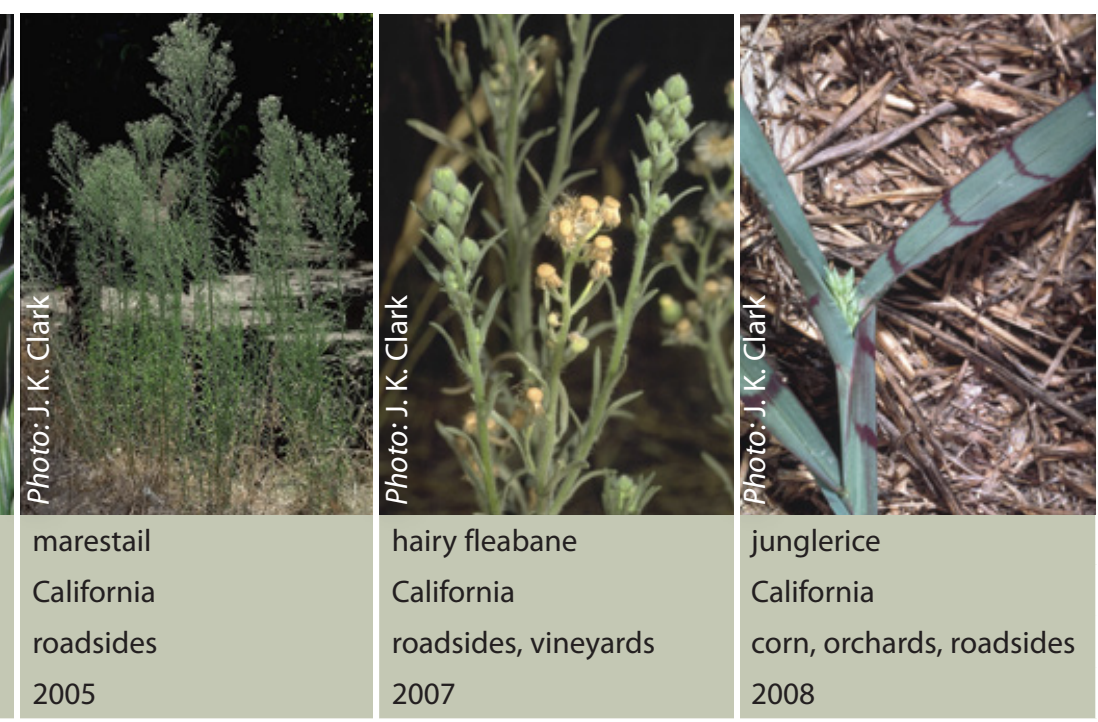

- field scouting

- sanitation, including field margins and cleaning equipment

- crop rotation

- cover crops

- tillage practices

- selection of well-adapted, high-performance varieties or hybrids with early-season vigor to compete with weeds

- optimal planting date, seeding rate, and spacing

- timely and efficient irrigation

- proper timing, placement, and rates of nutrients

- monitoring of weeds before and after herbicide application to check for weed control patterns that are consistent with application problems or selection for resistant weeds

- mechanical cultivation

- biological methods

- herbicide applications 
- preplanting and preemergence herbicides followed by glyphosate treatments

- application of glyphosate when weeds are at a sensitive stage of development

- tank mixing of glyphosate with products that have a different mode of action

A single weed control measure is not likely to provide effective and sustainable weed management over time, as weed populations may have different responses to a single weed management practice. In addition, weeds have different life cycles and may escape treatment if they emerge after herbicide treatment, especially if a nonresidual herbicide is applied. Relying on one weed management practice can lead to weed shifts or selection for resistant biotypes; thus, it is critical to integrate as many weed management strategies as possible into a system. Glyphosate is a great weed management tool, but it must be used in conjunction with other herbicide types (other modes of action) and practices to ensure effective weed control in the short and long term.

In most western states, in-crop cultivation has traditionally been a significant component of weed management programs. In addition to controlling weeds, cultivation may improve earlyseason crop growth in compacted soils. On most soils, however, cultivation is of no value beyond weed control and can sometimes have negative effects. As more effective herbicides have become available, the need for cultivation has decreased. Over the past two decades, many growers have successfully eliminated cultivation, reducing equipment and labor costs, moisture loss, root damage, and subsequent weed flushes. However, eliminating cultivation can lead to more dependence on herbicides, which may hasten the development of herbicide-resistant weeds.

\section{Field Scouting}

Field monitoring and early detection of glyphosate-resistant weeds are the first and most important steps for preventing and managing glyphosate resistance. Scout fields frequently and be vigilant for patterns that indicate resistance. Before assuming that weeds that survived glyphosate application are resistant, rule out other factors that might have affected herbicide performance, such as misapplication, unfavorable weather conditions, improper application timing, and weed flushes after application. If multiple weed species are present in the field after glyphosate application, then it is likely that other factors related to performance, and not resistance, are responsible. If a single weed species remains in the field, however, this may indicate possible glyphosate resistance. If a high level of resistance is occurring in a field, you will observe dead plants next to uninjured or nearly uninjured plants, with a few intermediate-responding plants. If a low level of resistance is occurring in the field, dead plants will be right next to plants that appear nearly normal, with the majority of plants having an intermediate response. In early development stages of glyphosate resistance, it is common to observe patches of single weed species scattered in no particular pattern throughout the field.

\section{Herbicide Considerations in Glyphosate-Resistant Crops}

To prevent weeds from growing and to keep glyphosate-resistant weeds under control, incorporate multiple IPM tools into your weed management plan. The potential for developing glyphosateresistant weeds should receive serious and thoughtful attention when glyphosate-resistant crops are introduced. Resistance management must be an integral part of the production system. If selection pressure is maintained through the continuous use of the same herbicide, resistance is likely to soon render that herbicide ineffective.

Glyphosate controls a wide range of grasses, sedges, and broadleaf weeds and can be highly effective on deep-rooted perennials. The question is whether we can have an effective weed control program that is comprised only of postemergence glyphosate applications. This program would certainly cut down on costs, and it may work initially under certain field conditions, but problems with weed species shifts and glyphosate resistance may develop rapidly. The success of total postemergence glyphosate programs depends on what weeds are present in a field, their severity, proper timing of the herbicide application, and crop competitiveness. Fields with 
low weed pressure and few late-germinating weeds are most likely to have acceptable weed control with a total postemergence glyphosate program in the short term, but it is not sustainable and should be avoided. A combination of residual preemergence herbicides followed by postemergence tank mixtures of glyphosate with herbicides that have other modes of action is the ideal herbicide program.

If glyphosate is used as a burndown treatment prior to tillage, consider a tank mix of glyphosate with an herbicide that has another mode of action, such as an auxin-type herbicide. If you have glyphosate-resistant weeds such as marestail or hairy fleabane, tank mixes of glyphosate and 2,4-D can give good control, but the treatment must be made when the weeds are small. However, when contact nonselective herbicides such as paraquat replace glyphosate as a base program, antagonism has been reported for some tank-mix partners.

To maximize weed control, the timing of glyphosate application is vital in order to maximize weed control and minimize the chances of crop yield loss due to early-season weed competition. Our research has shown that glyphosate-resistant weeds are less resistant to glyphosate when they are young (i.e., 1 to 2 inches tall). Glyphosate should be applied in combination with herbicides that have other modes of action when weeds are small (i.e., 2 to 3 inches tall), if glyphosate-resistant weeds are present. Controlling weeds at this stage reduces the chances for crop yield loss as well as the risk of weed control failures with larger weeds that may be under stressful conditions.

Applying the appropriate glyphosate rate is another important consideration for consistent weed control. Proper glyphosate rates should be based on weed type, weed size, and spray volume. It is important to match the weed spectrum and size with the appropriate glyphosate rate to reduce chances of weed control failures under extreme conditions. In most cases, the appropriate rate to use for weed control in glyphosateresistant crops is 0.75 pounds acid equivalent per acre (a.e./ac) of glyphosate. However, larger and more difficult-to-control weeds may require higher rates (where the label allows). In addition, when glyphosate is tank mixed with other herbicides, select herbicide partners that are effective on weeds present in your field. For help in selecting proper herbicide partners, visit the University of California IPM Program's website (http://www.ipm.ucdavis.edu), consult the Pacific Northwest Weed Management Handbook (http:// pnwhandbooks.org/weed/), or contact your county extension office for local recommendations.

\section{Herbicide Options for Managing Glyphosate-Resistant Weeds}

Numerous options exist for managing glyphosate resistance, such as incorporating other herbicides into the system; using crop rotations with different growth cycles and herbicide programs; eliminating glyphosate selection pressure in the off-season; and, the simplest, avoiding practices that rely on controlling weeds entirely with glyphosate. The most important principle of glyphosate-resistance management is to prevent the survival and spread of glyphosate-resistant populations.

The following are generally recommended practices that growers or weed control managers should consider incorporating into their farming practices for managing glyphosate resistance:

- Use multiple herbicide modes of action, including those with residual effects, before applying glyphosate or tank mixing another herbicide with glyphosate.

- Apply herbicides at the recommended stage of weed growth as stated on the label.

- Include use of conventional herbicides, which can and should still be part of the grower's overall weed management system in glyphosateresistant cropping systems.

- Use full label glyphosate rates, since glyphosate resistance may be controlled by more than one gene.

Research has shown that management programs that use soilapplied herbicides followed by postemergence herbicides have less variability in weed control, crop yield, and net return compared with total postemergence programs. 


\section{Corn}

Under ideal conditions, preemergence programs may provide full-season weed control. This requires applying a combination of products at full label rates to extend control. Combining preemergence herbicides with postemergence herbicides or cultivation often provides more consistent weed control and protects crop yields better than one-pass preemergence or total postemergence programs. Application timing is critical to achieve the desired control with postemergence herbicides. Generally, weed tolerance to postemergence herbicides increases with plant height.

\section{Cotton}

The most effective weed management program includes combinations of soil-applied herbicides, cultivation, and postemergence herbicides. Glyphosate, however, is the primary herbicide used to control weeds in glyphosate-resistant cotton, and it provides excellent control in most situations. Two postemergence applications typically are required to achieve full-season control and protect yields. Using soil-applied herbicides in glyphosate-resistant cotton often improves the consistency of control and reduces early-season weed competition that can lead to crop yield loss. This practice also introduces herbicides with an alternative mode of action, reducing the selection pressure for glyphosate-resistant biotypes.

\section{Alfalfa}

Using glyphosate offers alfalfa growers an alternative weed management system that may enhance alfalfa growth and persistence by providing a wider spectrum of weed control. Glyphosate can be applied to glyphosate-resistant alfalfa at any stage of growth. Glyphosate-resistance management should always be implemented when using glyphosate-resistant alfalfa. Repeated applications of glyphosate may result in glyphosate-resistant weeds. Once glyphosate-resistant weeds become established within a field, glyphosate becomes ineffective against those weeds. Measures to reduce the potential of developing glyphosate-resistant weeds can include crop rotation, herbicide rotation, proper herbicide rate, proper herbicide timing, and alternative weed control methods.

\section{Canola}

Various options exist for preventing glyphosate resistance, depending on the weeds that are prevalent in a particular field. Rotate herbicides and use tank mixtures of glyphosate with herbicides that have other modes of action to reduce the chance of developing glyphosate resistance. Depending on the weed populations and pressure, growers should alter crop rotations and herbicide-tolerant canola system selections to ensure a diverse weed control program in the cropping system.

\section{Sugarbeet}

Using glyphosate for weed control is expected to make weed management simpler and more effective for sugarbeet growers. Conventional sugarbeet herbicides must contain many herbicidal ingredients in order to simultaneously manage all the different weed species, whereas glyphosate provides broad-spectrum weed control. Glyphosate may be used before sugarbeet is planted or as a postemergence herbicide after this crop is planted. It is critical to use a preemergence residual herbicide to achieve full-season control and protect yields. In addition, tank mix herbicides that have other modes of action with glyphosate to use prior to planting and during the growing season. Several postemergence herbicides available for sugarbeet have contact activity and may antagonize or reduce glyphosate activity, especially when glyphosate is used at low rates.

Measurement Conversion Table

\begin{tabular}{|l|c|c|l|}
\hline U.S. customary & $\begin{array}{c}\text { Conversion factor } \\
\text { for U.S. customary } \\
\text { to metric }\end{array}$ & $\begin{array}{c}\text { Conversion factor } \\
\text { for metric } \\
\text { to U.S. customary }\end{array}$ & Metric \\
\hline inch (in) & 2.54 & 0.394 & centimeter (cm) \\
\hline gallon (gal) & 3.785 & 0.264 & liter (l) \\
\hline pound (lb) & 0.454 & 2.205 & kilogram (kg) \\
\hline acre (ac) & 0.405 & 2.470 & hectare (ha) \\
\hline $\begin{array}{c}\text { pound per acre } \\
\text { (lb/ac) }\end{array}$ & 1.12 & 0.89 & kilogram per \\
hectare (kg/ha)
\end{tabular}




\section{FOR MORE INFORMATION}

To order or obtain ANR publications and other products, visit the ANR Communication Services online catalog at http://anrcatalog.ucanr.edu or phone 1-800-994-8849. You can also place orders by mail or FAX, or request a printed catalog of our products from

University of California

Agriculture and Natural Resources

Communication Services

1301 S. 46th Street

Building 478 - MC 3580

Richmond, CA 94804-4600

Telephone 1-800-994-8849

510-665-2195

FAX 510-665-3427

E-mail: anrcatalog@ucanr.edu

(92013 The Regents of the University of California

Agriculture and Natural Resources

All rights reserved.

\section{Publication 8494}

ISBN-13: 978-1-60107-845-2

The University of California Division of Agriculture \& Natural Resources (ANR) prohibits discrimination against or harassment of any person participating in any of ANR's programs or activities on the basis of race, color, national origin, religion, sex, gender identity, pregnancy (which includes pregnancy, childbirth, and medical conditions related to pregnancy or childbirth), physical or mental disability, medical condition (cancer-related or genetic characteristics), genetic information (including family medical history), ancestry, marital status, age, sexual orientation, citizenship, or service in the uniformed services (as defined by the Uniformed Services Employment and Reemployment Rights Act of 1994: service in the uni- formed services includes membership, application for membership, performance of service, application for service, or obligation for service in the uniformed services) or any person in any of its programs or activities.

University policy also prohibits retaliation against any employee or person participating in any of ANR's programs or activities for bringing a complaint of discrimination or harassment pursuant to this policy. This policy is intended to be consistent with the provisions of applicable State and Federal laws.

Inquiries regarding the University's equal employment opportunity policies may be directed to Linda Marie Manton, Affirmative Action Contact, University of California, Davis, Agriculture and Natural Resources, One Shields Avenue, Davis, CA 95616, 530-752-0495. For assistance in downloading this publication, telephone 530-754-3927.

To simplify information, trade names of products have been used. No endorsement of named or illustrated products is intended, nor is criticism implied of similar products that are not mentioned or illustrated.

An electronic copy of this publication can be found at the ANR Communication Services catalog website, http://anrcatalog.ucanr.edu/.

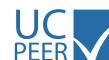

REVIEWED Management Joe Nunez.
web-7/13-LR/CR 